\title{
CONVERSION FROM GRASSLAND TO CROPLAND AND LENGTH OF CROPPING HISTORY DRIVING SOIL METHANE UPTAKE IN CHINA
}

\author{
YANG, W. $.^{1,3^{*}}-$ KANG, Y. ${ }^{1,2}-\mathrm{HOU}, \mathrm{J}^{3}-$ ZHAO, $\mathrm{J}^{3}$ \\ ${ }^{1}$ Inner Mongolia Potato Engineering \& Technology Research Center, College of Life Sciences, \\ Inner Mongolia University, Hohhot 010021, China \\ ${ }^{2}$ Institute of Geographic Sciences and Natural Resources Research, Chinese Academy of \\ Sciences, Beijing 100101, China \\ ${ }^{3}$ Inner Mongolia Key Laboratory of Environmental Chemistry, Hohhot 010022, China \\ *Corresponding author \\ e-mail: yangwzh@imnu.edu.cn \\ (Received $17^{\text {th }}$ Jan 2019; accepted $27^{\text {th }}$ Feb 2019)
}

\begin{abstract}
The change of land use from grassland to cropland in Northern China has raised serious concern about regional carbon $(\mathrm{C})$ cycle and greenhouse gas balance. We measured soil methane $\left(\mathrm{CH}_{4}\right)$ uptake using manual static chambers in grassland and cropland soils in the agro-pastoral ecotone of Inner Mongolia over three growing seasons (2010-2012). The primary aims were to assess the effect of undisturbed grassland and croplands from converted grassland with different land use histories on gas fluxes and systematically compare the site-specific $\mathrm{CH}_{4}$ uptake factor. We found a significant difference $(P<0.001)$ in $\mathrm{CH}_{4}$ uptake between grassland and croplands from reclaimed grassland for 5, 10 and 50 years old, and cropland soils in 5 and 10 years old were a significant sink of $\mathrm{CH}_{4}$. Compared with cropland soils, the grassland had the lowest cumulative $\mathrm{CH}_{4}$ uptake, with $141.4,210.0$ and $236.0 \mathrm{mg} / \mathrm{m}^{2}$ during growing seasons of 2010, 2011 and 2012, respectively. Over the 3 growing seasons, the cumulative $\mathrm{CH}_{4}$ uptake of croplands aged 5, 10 and 50 was $544.5,361.7$ and $266.1 \mathrm{mg} / \mathrm{m}^{2}$. With the increase of farming time, the methane accumulation and absorption of $\mathrm{C} 5, \mathrm{C} 10$ and $\mathrm{C} 50$ decreased. Differences in $\mathrm{CH}_{4}$ uptake of grassland and cropland with different length of cropping history can be explained by the amount of soil ammonium nitrogen $\left(\mathrm{NH}_{4}{ }^{+}-\mathrm{N}\right)$ and soil moisture. We conclude that ( $\mathrm{i}$ ) croplands for 5 and 10 years old from reclaimed grassland are the best approach considered here for optimizing the land use as a sink for atmospheric $\mathrm{CH}_{4}$, and ( ii ) the practice that croplands from grassland reclaimed for more than 10 years old should be planted into grasslands is recommended for managing $\mathrm{CH}_{4}$ uptake and soil carbon sink in the agro-pastoral ecotone of Inner Mongolia, China.

Keywords: land-use change, greenhouse gases, soil physical and chemical properties, carbon sink
\end{abstract}

\section{Introduction}

Methane $\left(\mathrm{CH}_{4}\right)$ is the second most important greenhouse gas in the atmosphere after carbon dioxide $\left(\mathrm{CO}_{2}\right)$. The atmospheric concentration of $\mathrm{CH}_{4}$ has been increasing by $0.3 \% / \mathrm{yr}$ (Liu et al., 2007). Although the main sink for atmospheric $\mathrm{CH}_{4}$ is its oxidation in the troposphere by hydroxyl(-OH) (Khalil, 2000), aerobic soils are the only biological sinks for atmospheric $\mathrm{CH}_{4}$ with an estimated global sink of 20-45 $\mathrm{Tg} \mathrm{CH}_{4} / \mathrm{yr}^{2}$ (IPCC, 2007). Methane uptake is influenced by several factors including land use change, temperature, precipitation, $\mathrm{N}$ input and soil properties (e.g., moisture, temperature, texture, $\mathrm{pH}$ and $\mathrm{C} / \mathrm{N}$ ratio) (Liu et al., 2009; Mou et al., 2014). Among these factors, land use change and soil properties are considered to be important drivers of the magnitude of methane uptake (Dörr et al., 1993; Ojima et al., 1993; Steudler et al., 1995). Changes in land use or intensification of land management directly affect the 
$\mathrm{CH}_{4}$ uptake and the atmospheric $\mathrm{CH}_{4}$ budget (Smith et al., 2000; Verchot et al., 2000; Merino et al., 2004).

Inner Mongolia steppes account for approximately $80 \%$ of grassland in China. Land use conversions from grassland to cropland have occurred in the arid and semi-arid lands of Asia (ASAL) during the 20th century. The agro-pastoral ecotone of Inner Mongolia is included in the ASAL of Asia. The transition from livestock grazing to farming causes changes in land use practice. The grassland in Inner Mongolia is a typical Leymus chinensis temperate steppe, where land use types are often diverse with frequent changes. Wang et al. (2005) and Liu et al. (2007) found that $\mathrm{CH}_{4}$ uptake rates and soil moisture were negatively correlated, while other soil properties were not discussed in these studies (Wang et al., 2005; Liu et al., 2007). How these changes have altered or will alter the $\mathrm{CH}_{4}$ uptake remains unknown. Moreover, although much is known regarding $\mathrm{CH}_{4}$ uptake, few data specific to soils of agro-pastoral ecotone is available, and few studies have been conducted on the effect of length of cropping history or soil properties on $\mathrm{CH}_{4}$ uptake in this region. The effects of the conversion of grassland to cropland on $\mathrm{CH}_{4}$ uptake are uncertain. The determining factors that mediate the influence of land use change on $\mathrm{CH}_{4}$ uptake have not been elucidated.

Therefore, we conducted a study in the agro-pastoral ecotone of Inner Mongolia to investigate the effects of land use change on $\mathrm{CH}_{4}$ uptake. The objectives were to understand the impact of cropping history and soil properties on $\mathrm{CH}_{4}$ uptake from the conversion of grassland to cropland. This study investigated $\mathrm{CH}_{4}$ uptake throughout 3 years in an agro-pastoral ecotone in Inner Mongolia, China. We compared cropland soils with different length of cropping history and adjacent grassland that were derived from the same parent material of soil under the same climate.

\section{Materials and methods}

\section{Description of the study site}

The study was conducted in Taipusi County, Inner Mongolia (China), located $41^{\circ} 49^{\prime} 52^{\prime \prime}$ north latitude and $115^{\circ} 13^{\prime} 26^{\prime \prime}$ east longitude, at an elevation of $1400 \mathrm{~m}$ above sea level (Fig. 1).

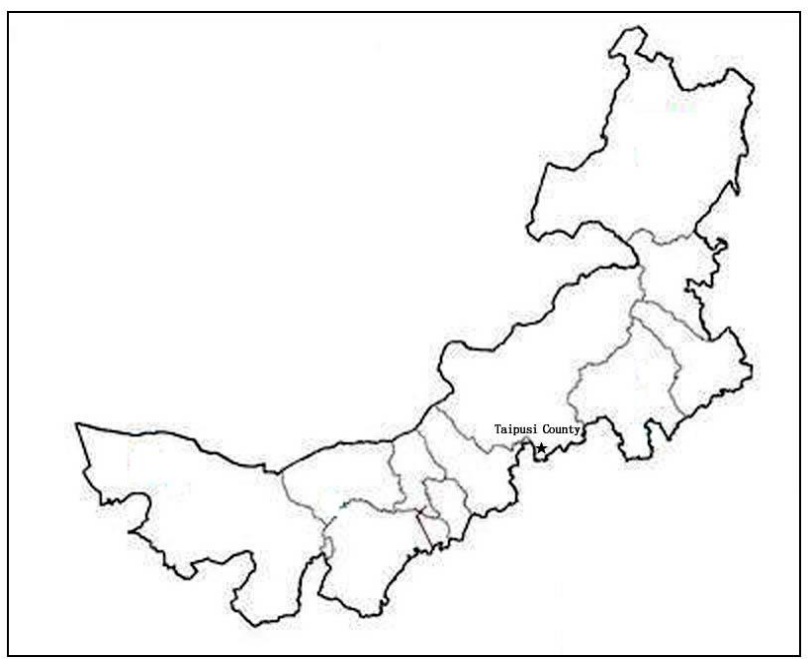

Figure 1. Location of study area in Inner Mongolia, China 
Located in the south of the Xilin River and characterized by scattered farms in the steppe, the study area is very representative of both the Eurasian temperate grasslands (Wang et al., 2007) and the steppe region of Inner Mongolia (Tong et al., 2004). The grassland is dominated by L. chinensis which is the typical vegetation of the region's grassland (Geng et al., 2010). The grassland in the study site was a natural clearing of native vegetation, without grazing or additional treatments such as fertilization or grass seeding. This region falls in the semi-arid temperate climatic zone. The mean annual temperature is approximately $1.6^{\circ} \mathrm{C}$, ranging from a mean monthly temperature of $17.6^{\circ} \mathrm{C}$ in January and $17.8^{\circ} \mathrm{C}$ in July. The region receives an average of $400 \mathrm{~mm}$ of precipitation annually. The growing season is from late April to early October.

Four sites were selected for the study, including an area of grassland (reference site) and croplands (farmer-managed fields) for 5, 10, and 50 years old from reclaimed grassland (Table 1). The length of cropping history was determined according to a field inventory and Taipusi County records. Hereafter, the four sites are referred to $G$ (grassland), C5 (5 y old cropland), C10 (10 y old cropland) and C50 (50 y old cropland). The 4 sites presented similar slope and soil type within the adjacent ecosystems including flat areas of grassland soil and cropland soil. N, P and K compound fertilizers were applied before planting. Agriculture management in C5, C10 and C50 soil after conversion was carried out similarly.

Table 1. Site characteristics of the agro-pastoral ecotone on Taipusi County, Inner Mongolia

\begin{tabular}{c|c|c|c}
\hline \multirow{2}{*}{ Site $^{\dagger}$} & \multicolumn{2}{|c|}{ Coordinates } & \multirow{2}{*}{ Land use history } \\
\cline { 2 - 3 } & Latitude N & Longitude E & Natural grassland \\
G & $41^{\circ} 49^{\prime} 52^{\prime \prime}$ & $115^{\circ} 13^{\prime} 26^{\prime \prime}$ & Cropland reclaimed for 5 years old \\
C5 & $41^{\circ} 50^{\prime} 29^{\prime \prime}$ & $115^{\circ} 13^{\prime} 19^{\prime \prime}$ & Cropland reclaimed for 10 years old \\
C10 & $41^{\circ} 50^{\prime} 49^{\prime \prime}$ & $115^{\circ} 13^{\prime} 43^{\prime \prime}$ & Cropland reclaimed for 50 years old \\
C50 & $41^{\circ} 50^{\prime} 53^{\prime \prime}$ & $115^{\circ} 13^{\prime \prime} 23^{\prime \prime}$ & \\
\hline
\end{tabular}

There were three replicates plots for every natural grassland $(\mathrm{G})$ and cropland from reclaimed grassland with different length of cropping history (C5, C10, and C50), respectively, and the area of each plot is $100 \mathrm{~m} \times 100 \mathrm{~m}$. Grassland vegetation was L. chinensis and Stipa capillata. Potatoes (KexinNO.1) and oats (Avena sativa L.) were grown in the three cropland sites in 2010, 2011 and 2012. Potatoes and Oats were alternatively planted in 2010, 2011 and 2012, respectively. Cropland was plowed once a year before planting. The plowing depth was $30-35 \mathrm{~cm}$ via machine plow. N, P and $\mathrm{K}$ compound fertilizer $\left(\mathrm{N}: \mathrm{P}_{2} \mathrm{O}_{5}: \mathrm{K}_{2} \mathrm{O}=15: 10: 10\right)(450 \mathrm{~kg} / \mathrm{ha})$ was incorporated into the soil before planting once a year. The crops were planted in May and were harvested in September, and the soil was bare from October to the following April. The croplands were irrigated in spring and autumn.

\section{Measurement of methane flux}

Field measurements of $\mathrm{CH}_{4}$ flux were conducted in the four soils from April 2010 to October 2012. Measurements were taken every 15 days between June and August and once a month in April, May, September and October.

Three square chambers $(n=3)$ were randomly placed in each plot replicate and were in the same location for the duration of the measurements. All the chambers were fixed to the ground, reaching approximately $10 \mathrm{~cm}$ down into the soil. Aluminum flux collars 
were permanently installed to ensure reproducible placement of the gas collection chambers for successive $\mathrm{CH}_{4}$ flux measurements throughout the growing season. The top edge of the collar had a groove that could be filled with water to seal the rim of the chamber. The chamber was equipped with a circulating fan to ensure complete gas mixing and was wrapped with a layer of sponge and aluminum foil to minimize air temperature changes inside the chamber during the period of the measurement. Cross-section of the chamber was $0.25 \mathrm{~m}^{2}(0.5 \mathrm{~m} \times 0.5 \mathrm{~m})$. The height of chamber (or H) was $0.5 \mathrm{~m}$. Samples were collected over a 30-min period $(0,10,20$ and $30 \mathrm{~min})$ after closing the chambers at 8:00-11:00 am. Gas samples were taken using $25 \mathrm{~mL}$ gas-tight plastic syringes which were closed with stopcocks. The air temperature inside the chamber was recorded by thermometer for each measurement. Soil temperature $(0-5 \mathrm{~cm}$ depth) was continuously recorded using temperature sensors interfaced with data loggers (HSY-TL881). During the $\mathrm{CH}_{4}$ flux measurement period, soil water content was monitored using a TDR instrument (MP-406 Kits for moisture measurement). Five temperatures and five soil moisture data were measured on each plot. The aboveground biomass of the potatoes and oats under the sampling chamber $\left(0.25 \mathrm{~m}^{2}\right)$ were determined by harvesting followed by oven-drying at $105^{\circ} \mathrm{C}$ to constant weight.

Air samples were analyzed for $\mathrm{CH}_{4}$ using a modified gas chromatograph (Agilent 6820D, Agilent Corporation) equipped with a flame ionization detector (FID) (Wang and Wang, 2003). Nitrogen was used as the carrier gas $(30 \mathrm{~mL} / \mathrm{min})$. The oven was operated at $55^{\circ} \mathrm{C}$ and the FID was operated at $200^{\circ} \mathrm{C}$. Flux was determined from the slope of the mixing ratio change in four samples taken $0,10,20$ and $30 \mathrm{~min}$ after chamber closure. The gas samples were rejected if they did not yield an $\mathrm{R}^{2}$ greater than 0.90 over the 30 min period. If the detected mixing ratio in the samples is decreased with the prolonging of time, it is a negative value, representing uptake. Carbon sinks into soil. Otherwise, it represents emissions.

\section{Flux calculation}

The $\mathrm{CH}_{4}$ flux was calculated with Eq. 1 (Yang et al., 2018):

$$
F=1000 \cdot S \cdot H \cdot M \cdot(P a / P s) \cdot(T s / T a) / 22.4
$$

where $F$ refers to $\mathrm{CH}_{4}$ flux $\left(\mu \mathrm{g} /\left(\mathrm{m}^{2} \mathrm{~min}\right)\right), S$ is the linear slope of the concentration change with time over the measurement period $(\mu \mathrm{L} /(\mathrm{L} \min )), H$ is the valid height of the sampling chamber (m) and $M$ is the molar mass of $\mathrm{CH}_{4}(16 \mathrm{~g} / \mathrm{mol}) . P a$ and $T a$ are the actual measured atmospheric pressure and temperature inside the chamber, respectively. $P s$ and $T s$ are the standard conditions $(760 \mathrm{~mm} \mathrm{Hg}, 273.15 \mathrm{~K})$. The standard molar volume of $\mathrm{CH}_{4}(\mathrm{~L} / \mathrm{mol})$ is 22.4 . Seasonal (7 month values) amounts of $\mathrm{CH}_{4}$ uptakes were sequentially accumulated from the uptakes between every two adjacent intervals of the measurements.

\section{Soil property measurements}

Soil samples were collected for chemical analysis during the $\mathrm{CH}_{4}$ flux measurements. The measurements were taken once every 15 days from June to August and once a month in April, May, September and October. Three replicates were collected from each site (G, C5, C10 and C50), with 10 sampling locations for each composite replicate. The samples were air-dried and sifted through $2 \mathrm{~mm}$ for 
physicochemical analysis. The sample of soil bulk density was collected using a steel cylinder ( $5 \mathrm{~cm}$ of diameter, $5 \mathrm{~cm}$ of height). Soil organic carbon (SOC), total nitrogen (TN), $\mathrm{NH}_{4}{ }^{+}-\mathrm{N}$ and $\mathrm{NO}_{3}{ }^{-} \mathrm{N}$ were determined following procedures. SOC was determined using a TOC (Total Organic Carbon) analyzer (Sievers $5310 \mathrm{C}$, GE Analytical Instruments, USA) (Lim and Choi, 2014), and TN was measured via the dry combustion method using a C/N Analyzer (Vario Macro, Elementar, Germany) (Yan et al., 2012). Soil ammonium nitrogen $\left(\mathrm{NH}_{4}{ }^{-}-\mathrm{N}\right)$ and nitrate nitrogen $\left(\mathrm{NO}_{3}{ }^{-} \mathrm{N}\right)$ were measured using a micro-Kjeldahl procedure (Aulakh et al., 2000). Soil microbial biomass C (MBC) and microbial biomass $\mathrm{N}(\mathrm{MBN})$ were determined using the chloroform $\left(\mathrm{CHCl}_{3}\right)$ fumigation-incubation method (Nunan et al., 1997). The $\mathrm{pH}$ value was measured in 1:2.5 soil/ $\mathrm{H}_{2} \mathrm{O}(\mathrm{w} / \mathrm{w})$ suspension with a Titrino $\mathrm{pH}$ meter (Metrohm Ltd. CH.-901, Herisau, Switzerland) fitted with a glass electrode (Godsey et al., 2007).

\section{Data analysis}

Data were analyzed using ANOVAs and General Linear Mixed Model to assess the effect of the study site. Pearson's correlation analysis was performed to investigate the relationship between $\mathrm{CH}_{4}$ uptake and soil properties (i.e., soil temperature, soil moisture and soil $\mathrm{NH}_{4}{ }^{+}-\mathrm{N}$ content etc.). The $R^{2}$ (square of Pearson correlation coefficient) values were used to determine the fitness of regression functions. For all analysis, statistical significance was determined at $P<0.05$. All statistical analyses were performed using SPSS 11.5 (SPSS Inc., Chicago, IL, USA).

\section{Results}

\section{Seasonal change on $\mathrm{CH}_{4}$ uptake flux from the soils of grassland and croplands with} different ages reclaimed

The $\mathrm{CH}_{4}$ uptake flux in the grassland, $\mathrm{C} 5, \mathrm{C} 10$, and $\mathrm{C} 50$ soils showed obvious seasonal variability from 2010 to 2012 in the study (Fig. 2). During the first month of the growing season, $\mathrm{CH}_{4}$ uptake increased rapidly in $\mathrm{C}_{5}$ soil. However, the seasonal uptake of $\mathrm{CH}_{4}$ in $\mathrm{G}$ and $\mathrm{C} 50$ soils increased moderately, and there was no significant uptake peak. Throughout the testing stage, $\mathrm{CH}_{4}$ uptake was lower in grassland and $\mathrm{C} 50$ soil than that in $\mathrm{C} 5$ and $\mathrm{C} 10$ soils. The maximum uptake flux of $\mathrm{CH}_{4}$ in the grassland soil was $0.06,0.12$ and $0.11 \mathrm{mg} /\left(\mathrm{m}^{2} \mathrm{hr}\right)$, and was $0.09,0.13$ and $0.20 \mathrm{mg} /\left(\mathrm{m}^{2} \mathrm{hr}\right)$ in the C50 soil during the growing seasons in 2010, 2011 and 2012, respectively (Fig. 2). $\mathrm{CH}_{4}$ uptake flux was the highest in $\mathrm{C} 5$ and $\mathrm{C} 10$ soils during the experimental period. The peak of $\mathrm{CH}_{4}$ uptake flux in $\mathrm{C} 5$ and $\mathrm{C} 10$ soils was detected between June and July. The maximum $\mathrm{CH}_{4}$ uptake flux of $\mathrm{C} 5$ soil was $0.27,0.23$ and $0.29 \mathrm{mg} /\left(\mathrm{m}^{2} \mathrm{hr}\right)$, and was 0.22 , 0.20 and $0.29 \mathrm{mg} /\left(\mathrm{m}^{2} \mathrm{hr}\right)$ in $\mathrm{C} 10$ soil in 2010, 2011 and 2012, respectively. $\mathrm{CH}_{4}$ uptake declined in all of the study sites at the end of the growing season (Fig. 2).

\section{Cumulative methane uptake in the soils of grassland and croplands with different land use history}

There were significant differences for cumulative $\mathrm{CH}_{4}$ uptake in the grassland soil, C5, C10, and C50 cropland soils in $2010(F=273.7, P<0.0001), 2011$ ( $F=264.8$, $P<0.0001)$ and $2012(F=362.4, P<0.0001)$. The land use conversion in more recently-established croplands (5 and 10 years old) from grassland to cropland promoted greater atmospheric $\mathrm{CH}_{4}$ uptake compared to $\mathrm{C} 50$ and grassland type. 
The grassland and $\mathrm{C} 50$ soils exhibited lower cumulative $\mathrm{CH}_{4}$ uptake with 141.4 and $224.0 \mathrm{mg} / \mathrm{m}^{2}$ than that of the C10 and C50 soils in 2010, 2011 and 2012, respectively (Fig. 3). Cumulative $\mathrm{CH}_{4}$ uptake during the growing season was 544( \pm 103$)$ and $361( \pm 47) \mathrm{mg} / \mathrm{m}^{2}$ in C5 and C10 soils, respectively. The cumulative uptake flux in C5, C10, and C50 soils was 190\%, 90\% and 38\% higher than that of the grassland soil. As the cropping history increased, the cumulative $\mathrm{CH}_{4}$ uptake decreased in $\mathrm{C} 5, \mathrm{C} 10$, and C50 soils.

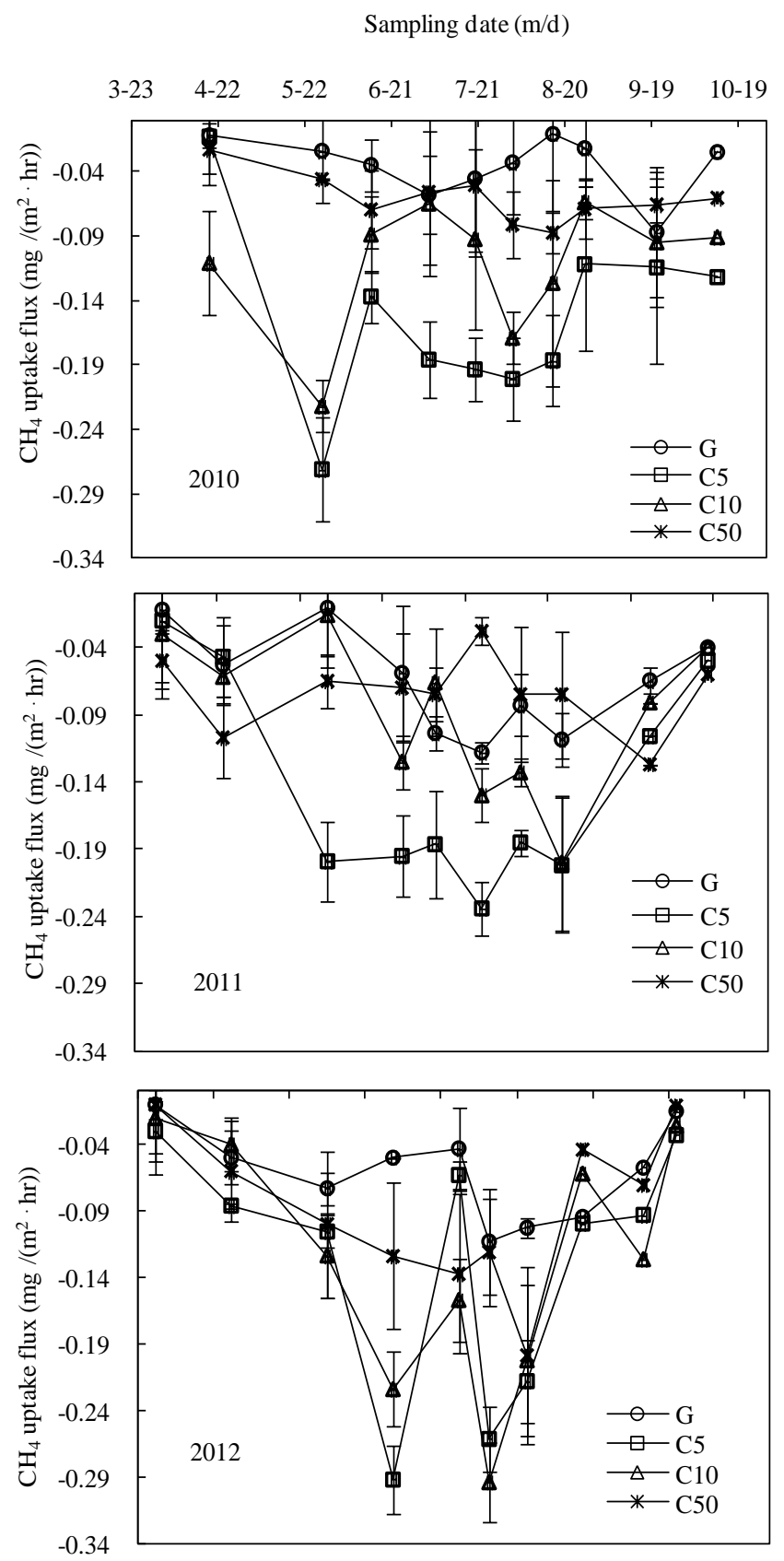

Figure 2. Seasonal $\mathrm{CH}_{4}$ uptake flux from the grassland and cropland with different length of cropping history during the growing season in 2010, 2011, and 2012; G: natural grassland; C5, C10, and C50: cropland for 5,10, and 50 years old from reclaimed grassland, respectively; The vertical bars represent standard error 


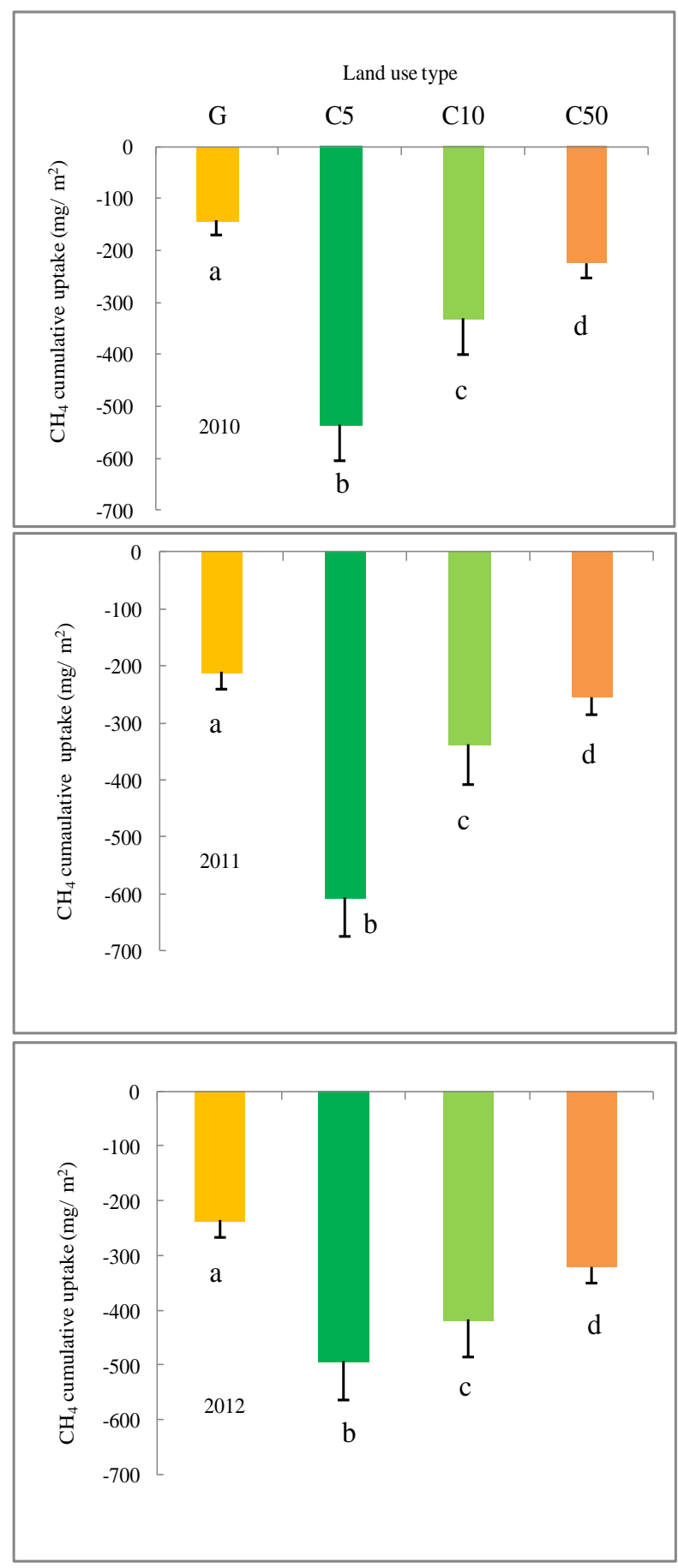

Figure 3. Cumulative $\mathrm{CH}_{4}$ uptake from the grassland and cropland soils during the growing seasons in 2010, 2011, and 2012; G: natural grassland; C5, C10, and C50: cropland for 5,10, and 50 years old from reclaimed grassland, respectively; The vertical bars represent standard error; different letters represent significant differences between the treatments

The changing relationship between $\mathrm{CH}_{4}$ uptake and moisture or temperature of soil from different land use types

A significantly negative correlation in grassland, C5, C10, and C50 soils $(r=0.52$, $0.75,0.63,0.62 ; P<0.01)$ was detected between $\mathrm{CH}_{4}$ uptake flux and soil volumetric 
moisture $(\% \mathrm{v} / \mathrm{v})$ when soil temperature was above $5^{\circ} \mathrm{C}($ Fig. $4 a-d)$. Soil moisture was a major factor affecting $\mathrm{CH}_{4}$ uptake flux in the soils. The correlation between temperature and $\mathrm{CH}_{4}$ uptake flux was not observed in the soils $(P>0.05)$ (Fig. 5). Soil moisture was the important controlling factor for $\mathrm{CH}_{4}$ uptake flux when the temperature was not the limiting factor.
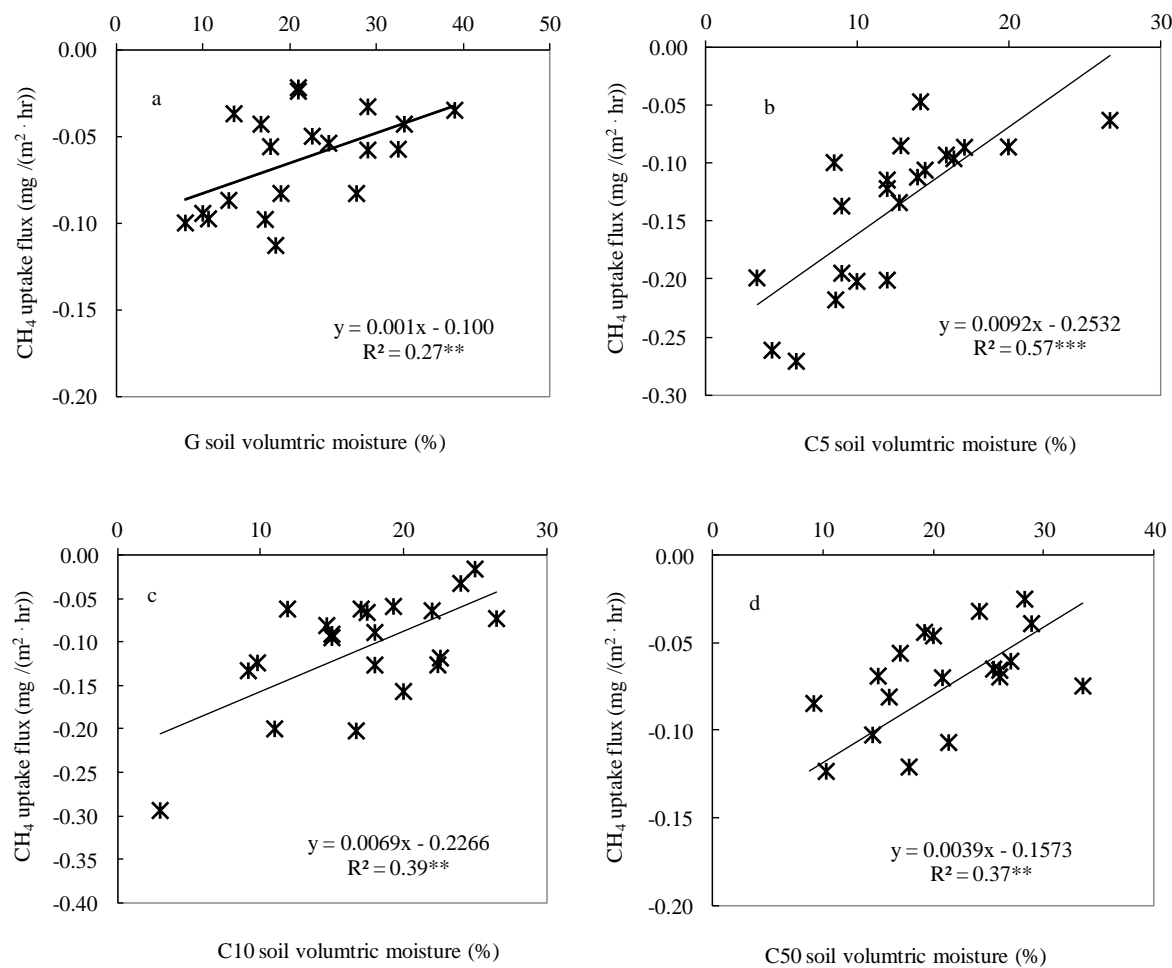

Figure 4. Correlation between $\mathrm{CH}_{4}$ uptake flux and soil moisture from grassland and cropland soils; The soil volumetric moisture was simultaneously measured when gas sample were collected from 2010 to 2012; C5, C10, and C50: cropland for 5, 10, and 50 years old from reclaimed grassland, respectively

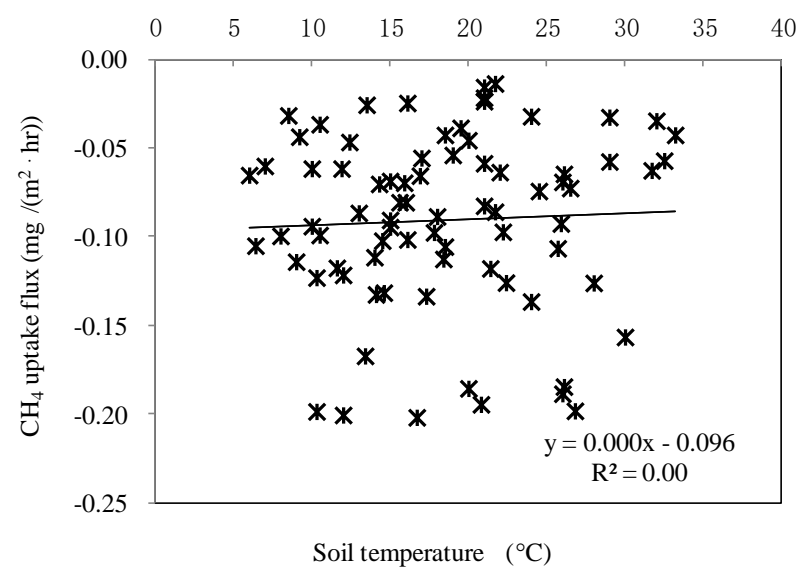

Figure 5. Correlation between $\mathrm{CH}_{4}$ uptake flux and soil temperature in grassland and cropland soils; Soil temperature was simultaneously measured when gas sample were collected from 


\section{Potential links between cumulative methane uptake and soil $\mathrm{NH}_{4}{ }^{+}-\mathrm{N}$}

A negative relationship $(r=-0.86 ; P<0.01)$ was found between cumulative $\mathrm{CH}_{4}$ uptake and soil $\mathrm{NH}_{4}{ }^{+}-\mathrm{N}$ in the soils (Fig. 6). Soil $\mathrm{NH}_{4}{ }^{+}-\mathrm{N}$ and $\mathrm{NO}_{3}{ }^{-}-\mathrm{N}$ were greater in the cropland soils than that in the grassland soil in our study (Table 2). The soils with a high $\mathrm{NH}_{4}{ }^{+}-\mathrm{N}$ content showed lower cumulative $\mathrm{CH}_{4}$ uptake. However, no correlation was observed between cumulative $\mathrm{CH}_{4}$ uptake and soil $\mathrm{NO}_{3}{ }^{-} \mathrm{N}$ in the growing season. The regression analysis indicated that a linear combination of soil $\mathrm{NH}_{4}{ }^{+}-\mathrm{N}$ explained more than $73 \%$ of the variability in the cumulative $\mathrm{CH}_{4}$ uptake, and may account for the difference of the cumulative $\mathrm{CH}_{4}$ uptake in the soils (Fig. 6).

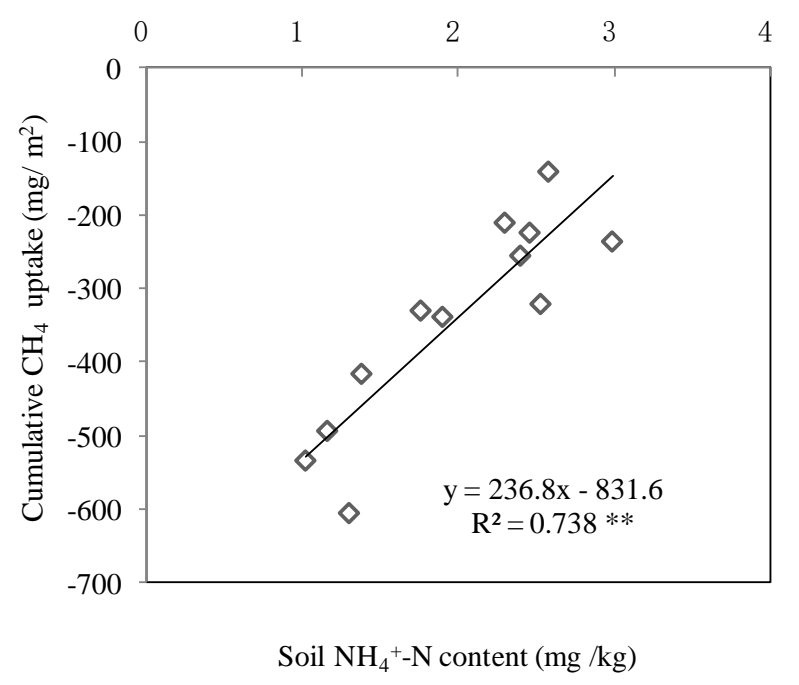

Figure 6. Correlation between cumulative $\mathrm{CH}_{4}$ uptake and soil $\mathrm{NH}_{4}{ }^{+}-\mathrm{N}$ in grassland and cropland soils; $\mathrm{NH}_{4}{ }^{+}-\mathrm{N}$ content was seasonal mean value from 2010 to 2012

Table 2. Physical and chemical properties of grassland and cropland soils with different length of ropping history (means $\pm S D$ )

\begin{tabular}{|c|c|c|c|c|c|c|c|c|c|}
\hline Years & $\begin{array}{l}\text { Soil } \\
\text { code }\end{array}$ & $\underset{\%}{\mathrm{~S} O \mathrm{COC}}$ & $\begin{array}{c}\text { TN } \\
\text { g kg-1 }^{-1}\end{array}$ & $\begin{array}{c}\text { Soil bulk } \\
\text { density } \\
\mathrm{g} \mathrm{cm}^{-3}\end{array}$ & pH & $\begin{array}{c}\ddagger \mathrm{MBC} \\
\mathrm{mg} \mathrm{kg}^{-1}\end{array}$ & $\begin{array}{c}\text { MBN } \\
\text { mg kg-1 }^{-1}\end{array}$ & $\begin{array}{l}\mathrm{NH}_{4}{ }^{+}-\mathrm{N} \\
\mathrm{mg} \mathrm{kg}^{-1}\end{array}$ & $\begin{array}{l}\mathrm{NO}_{3}-\mathrm{N} \\
\mathrm{mg} \mathrm{kg}^{-1}\end{array}$ \\
\hline \multirow{4}{*}{2010} & ${ }^{\dagger} \mathrm{G}$ & $2.46 \pm 0.01$ & $0.25 \pm 0.01$ & $1.42 \pm 0.18$ & $8.0 \pm 0.05$ & $271 \pm 33.3$ & $105 \pm 28.0$ & $1.02 \pm 0.35$ & $7.08 \pm 9.78$ \\
\hline & $\mathrm{C} 5$ & $1.58 \pm 0.05$ & $0.17 \pm 0.01$ & $1.32 \pm 0.08$ & $7.6 \pm 0.08$ & $976 \pm 146.2$ & $66 \pm 4.6$ & $2.58 \pm 0.45$ & $10.36 \pm 7.73$ \\
\hline & $\mathrm{C} 10$ & $1.30 \pm 0.02$ & $0.13 \pm 0.01$ & $1.20 \pm 0.02$ & $7.6 \pm 0.01$ & $454 \pm 42.1$ & $51 \pm 13.3$ & $2.46 \pm 0.22$ & $20.10 \pm 14.89$ \\
\hline & $\mathrm{C} 50$ & $0.79 \pm 0.13$ & $0.09 \pm 0.01$ & $1.40 \pm 0.06$ & $7.6 \pm 0.03$ & $442 \pm 46.2$ & $36 \pm 10.5$ & $1.76 \pm 0.32$ & $24.89 \pm 12.42$ \\
\hline \multirow{4}{*}{2011} & G & & & & & $232 \pm 47.4$ & $49 \pm 9.7$ & $1.30 \pm 0.30$ & $8.00 \pm 0.84$ \\
\hline & $\mathrm{C} 5$ & & & & & $857 \pm 89.1$ & $48 \pm 20.8$ & $2.50 \pm 0.20$ & $13.60 \pm 1.21$ \\
\hline & $\mathrm{C} 10$ & & & & & $426 \pm 72.5$ & $25 \pm 9.2$ & $2.40 \pm 0.10$ & $20.00 \pm 3.84$ \\
\hline & $\mathrm{C} 50$ & & & & & $272 \pm 106.3$ & $22 \pm 5.3$ & $1.90 \pm 0.13$ & $32.00 \pm 2.09$ \\
\hline \multirow{4}{*}{2012} & $G$ & & & & & $183 \pm 38.5$ & $48 \pm 9.8$ & $1.16 \pm 0.37$ & $7.30 \pm 1.60$ \\
\hline & $\mathrm{C} 5$ & & & & & $885 \pm 36.2$ & $37 \pm 12.0$ & $2.99 \pm 0.36$ & $10.60 \pm 1.12$ \\
\hline & $\mathrm{C} 10$ & & & & & $365 \pm 23.6$ & $30 \pm 11.2$ & $2.53 \pm 0.38$ & $11.00 \pm 1.04$ \\
\hline & $\mathrm{C} 50$ & & & & & $233 \pm 28.3$ & $15 \pm 6.4$ & $1.38 \pm 0.75$ & $23.60 \pm 3.03$ \\
\hline
\end{tabular}

${ }^{\dagger} \mathrm{G}$ : natural grassland; C5, C10, and C50: cropland for 5, 10, and 50 years old from reclaimed grassland

* SOC: soil organic carbon; BD: bulk density; TN: soil total nitrogen

^MBC: microbial biomass C; MBN: microbial biomass $\mathrm{N}$ 


\section{Discussion}

\section{Cropland soils from reclaimed grassland increasing methane uptake}

The $\mathrm{CH}_{4}$ uptake flux in the grassland soil was $0.001-0.120 \mathrm{mg} /\left(\mathrm{m}^{2} \mathrm{hr}\right)$ from 2010 to 2012 in our study. This falls in the range of a study conducted by Wang et al. (2015) $\left(0.017-0.162 \mathrm{mg} /\left(\mathrm{m}^{2} \mathrm{hr}\right)\right)$ in a typical steppe dominated by Leymus chinensis (Trin.) Tzvel at Guyuan State Key Monitoring and Research Station of Grassland Ecosystem (Wang et al., 2015). In our study, the cropland soil after conversion from grassland to cropland increased the $\mathrm{CH}_{4}$ uptake from 2010 to $2012\left(141-235 \mathrm{mg} / \mathrm{m}^{2}\right.$ in $\mathrm{G}$, $534-737 \mathrm{mg} / \mathrm{m}^{2}$ in $\mathrm{C} 5,210-605 \mathrm{mg} / \mathrm{m}^{2}$ in $\mathrm{C} 10$, and $235-493 \mathrm{mg} / \mathrm{m}^{2}$ in $\left.\mathrm{C} 50\right)$. We found that the croplands from reclaimed grassland accelerated the $\mathrm{CH}_{4}$ uptake. Compared to natural grasslands, agricultural soils from reclaimed grassland experience more physical disturbance due to fertilizer application as well as plowing, planting and harvesting with heavy agricultural equipment, which increases the aeration and porosity of the soils, affects mineralizable carbon and the other biochemical attributes (Rong et al., 2015), and creates favorable conditions for $\mathrm{CH}_{4}$ oxidation. The oxidation of atmospheric $\mathrm{CH}_{4}$ in upland soils is a biological process governed by $\mathrm{CH}_{4}$-oxidizing bacteria and is dependent on the availability of both $\mathrm{CH}_{4}$ and oxygen $\left(\mathrm{O}_{2}\right)$ in the soil profile (Yang et al., 2018). Boeckx et al. (1997) also reported that grassland had a lower methane uptake capacity than arable land in a study conducted in Belgium.

\section{Decreasing methane uptake in cropland soils with the increase of cropping history from reclaimed grassland}

$\mathrm{CH}_{4}$ uptake rule on a temporal trend of cropping history was discovered in the agropastoral ecotone of Inner Mongolia. $\mathrm{CH}_{4}$ uptake in cropland soil decreased with the increase of cropping history from 5 to 50 years after the grassland was converted into cropland (Fig. 3). Higher $\mathrm{CH}_{4}$ uptake in the cropland soils from $\mathrm{C} 5$ and $\mathrm{C} 10$ was found in more recently-established croplands. The $\mathrm{CH}_{4}$ uptake of $\mathrm{C} 50$ soil is close to that of grassland soil. Changes in soil carbon and soil properties after long-term fertilizer application affect methane oxidative bacteria community structure and soil methane oxidation rate (Hütsch et al., 1993). To reduce $\mathrm{CH}_{4}$ uptake was proved on a period (7 years) of inorganic nitrogen application (Mosier et al., 1998). This study showed that enhancing or reducing $\mathrm{CH}_{4}$ uptake by soil cultivation depends partly on the time elapsed from the conversion of grassland to cropland. In the field experiment, none of the $\mathrm{CH}_{4}$ uptake was correlated with potatoes and oats biomass production $(P>0.05)$.

\section{Methane uptake driven by the soil physicochemical properties of different land use type}

Our study showed that the conversion of natural grassland to cultivated land can temporarily increase the uptake of $\mathrm{CH}_{4}$ from the atmosphere depending on soil moisture level and soil $\mathrm{NH}_{4}{ }^{+}-\mathrm{N}$. Soil moisture ranged from 6\%-26\% in $\mathrm{C} 5,3 \%-25 \%$ in $\mathrm{C} 10$, and 9\%-34\% in C50. Soil moisture in grassland is the highest (8\%-39\%) from 2010 to 2012. $\mathrm{CH}_{4}$ uptake decreased as soil moisture level increased, which is consistent with previous studies (Price et al., 2004). There was negative correlation between $\mathrm{CH}_{4}$ uptake and soil moisture in a semi-arid steppe. Moisture content is an important factor on regulating the transport process of methane from soil macro pores to methane oxidizing bacteria and the diffusion of methane into the soil (Wang et al., 2005; IPCC, 2007). Quantity and activity of methanotrophs significantly reduce on higher moisture levels in the soil 
(Castro et al., 1992; Sitaula et al., 1995). As soil moisture increases, the soil microbial community is covered by a thick water film which reduces the microorganisms activity and hinders the spread of $\mathrm{CH}_{4}$ oxidation. $\mathrm{CH}_{4}$ in soil water diffuses at a slower rate compared to soil air.

The effect of temperature on $\mathrm{CH}_{4}$ uptake capacity in our study was not pronounced between $10^{\circ} \mathrm{C}$ and $26^{\circ} \mathrm{C}$ in grassland soil and cropland soils (Fig. 5). Castro et al. (1995) found that soil temperature was not an important controller of $\mathrm{CH}_{4}$ uptake when temperature ranged between $10^{\circ} \mathrm{C}$ and $20^{\circ} \mathrm{C}$ (Castro et al., 1995). Warming $\left(4.5^{\circ} \mathrm{C}\right.$ ) increased the average seasonal $\mathrm{CH}_{4}$ uptake by $65.9 \%$ in the permafrost region of an alpine meadow (Chen et al., 2017). Soil moisture on $\mathrm{CH}_{4}$ uptake was more important than temperature when the temperature was not the limiting factor. Irrigation and management in cropland create an optimum temperature for soil methanotrophs. The seasonality of $\mathrm{CH}_{4}$ uptake exhibited a strong dependency on the seasonal variation of soil moisture in a typical semi-arid steppe in Inner Mongolia (Chen et al., 2010).

The negative correlation between $\mathrm{CH}_{4}$ uptake and soil $\mathrm{NH}_{4}{ }^{+}-\mathrm{N}$ is detected over the whole testing stage $(r=0.86, n=12)$. This result was consistent with previous findings in an incubation experiment under ambient $\mathrm{CH}_{4}$ levels (Chan and Parkin, 2001). Soil $\mathrm{NH}_{4}{ }^{+} \mathrm{N}$ is a key determinant on $\mathrm{CH}_{4}$ oxidation capacity due to the significant competitive inhibition of $\mathrm{CH}_{4}$ uptake by $\mathrm{NH}_{4}{ }^{+}-\mathrm{N}$ in recently cultivated soils (Jacinthe and Lal, 2005).

There were no significant correlations between $\mathrm{CH}_{4}$ uptake and soil properties such as SOC content, MBN concentration, $\mathrm{MBC}, \mathrm{TN}$, soil sand content, $\mathrm{pH}$, soil clay content and soil bulk density in all of the soils $(P>0.05)$ (Table 2, Fig. 3). As there was no significant difference for SOC, TN, soil bulk density and $\mathrm{pH}$ between the four types of land use in 2010. In addition, they change more slowly than other physicochemical properties such as $\mathrm{NH}_{4}{ }^{+}-\mathrm{N}, \mathrm{NO}_{3}{ }^{-} \mathrm{N}, \mathrm{MBN}$, and $\mathrm{MBC}$. Therefore, these data were not measured in 2011 and 2012. Variation in soil moisture and soil $\mathrm{NH}_{4}{ }^{+}-\mathrm{N}$ may have concealed the changes in soil bulk density, SOC, TN, soil MBN content, MBC, soil clay content and soil $\mathrm{pH}$ from land use change, although $\mathrm{CH}_{4}$ uptake is affected by various factors. In our study, soil moisture (Fig. 4) and soil $\mathrm{NH}_{4}{ }^{+}-\mathrm{N}$ content (Fig. 6) were the major factors determining the difference on $\mathrm{CH}_{4}$ uptake between grassland and cultivated land.

This study was designed to address how land use change affects $\mathrm{CH}_{4}$ uptake and what soil parameters are the most important for assessing $\mathrm{CH}_{4}$ uptake from the conversion of grassland to cropland in the agro-pastoral ecotone of Inner Mongolia. These efforts will improve our understanding of land use change on the $\mathrm{CH}_{4}$ uptake in the agro-pastoral ecotone. The observed effects of physical and chemical properties of soil on $\mathrm{CH}_{4}$ uptake in this study will support to estimate $\mathrm{CH}_{4}$ fluxes based on soil properties from different land use types using model and simulation method. However, in our study, we examined the effects of land conversion on soil methane uptake in Inner Mongolia. The effects of nitrogen fertilizer application on methane uptake in croplands and grassland need to be further studied in the future.

\section{Conclusions}

The four land-use types ( $\mathrm{G}, \mathrm{C} 5, \mathrm{C} 10$ and C50) that we studied in the semi-arid steppe of the agro-pastoral region of northern China were sinks for atmospheric $\mathrm{CH}_{4}$ with an average uptake flux of $0.06-0.29 \mathrm{mg} \mathrm{m}^{-2} \mathrm{hr}^{-1}$. Cropping history of the conversion from 
grassland to cropland affects $\mathrm{CH}_{4}$ uptake. Land-use types exhibited different soil $\mathrm{CH}_{4}$ fluxes with the maximum $\mathrm{CH}_{4}$ uptake occurring in the $\mathrm{C} 5$ land-use type, and $\mathrm{CH}_{4}$ uptake was higher for $\mathrm{C} 10$ compared to $\mathrm{C} 50$ type. The $\mathrm{CH}_{4}$ uptake of $\mathrm{C} 50$ soil was approximately equal to that of grassland soil. Soil moisture and soil $\mathrm{NH}_{4}{ }^{+}-\mathrm{N}$ content are the key driving factor on $\mathrm{CH}_{4}$ uptake of the observed differences between grassland and arable lands with different reclaimed history and may provide a possible approach for estimating soil $\mathrm{CH}_{4}$ fluxes. Our results contribute to understanding soil uptake levels of atmospheric $\mathrm{CH}_{4}$ in four important land-use types in northern China. The cropland reclaimed more than 10 years old should be planted into grasslands to facilitate $\mathrm{CH}_{4}$ uptake and soil carbon sequestration in the agro-pastoral ecotone of Inner Mongolia. However, how long will the cultivated grassland be grazed and reclaimed into cropland be conducive to carbon sink? These tasks need to be studied in the future.

Acknowledgements. We sincerely appreciate the anonymous reviewers for their critical and valuable comments to help improve this manuscript. We thank colleagues of Chemistry and Environmental Sciences College, Inner Mongolia Normal University, for their help in laboratory analyses. postgraduate Jianghong Zhao and Jianhua Hou for their assistance in situ observation and measurement, undergraduate Lei Ma and Zhiwei Liu. The project was funded under the auspices of National Natural Science Foundation of China (No. 41565009, 41675140, 41865010), The National Key Research and Development Program of China, grant number (No. 2016YFC0400105), Inner Mongolia Youth Innovative Talent Training Program of Prairie Excellence Project 2016.

\section{REFERENCES}

[1] Aulakh, M. S., Khera, T. S., Doran, J. W. (2000): Mineralization and denitrification in upland, nearly saturated and flooded subtropical soil I. Effect of nitrate and ammoniacal nitrogen. - Biology and Fertility of Soils 31: 162-167.

[2] Boeckx, P., VanCleemput, O., Villaralvo, I. (1997): Methane oxidation in soils with different textures and land use. - Nutrient Cycling in Agroecosystems 49: 91-95.

[3] Castro, M. S., Steudler, P. A., Melillo, J. M. (1992): Exchange of $\mathrm{N}_{2} \mathrm{O}$ and $\mathrm{CH}_{4}$ between the atmosphere and soils in spruce fir forests in the Northeastern United States. Biogeochemistry 18: 119-135.

[4] Castro, M. S., Steudler, P. A., Melillo, J. M., Aber, J. D. (1995): Factors controlling atmospheric methane consumption by temperate forest soils. - Global Biogeochemical Cycles 9: 1-10.

[5] Chan, A. S. K., Parkin, T. B. (2001): Methane oxidation and production activity in soils from natural and agricultural ecosystems. - Journal of Environmental Quality 30: 18961903.

[6] Chen, W. W., Benjamin, W., Yao, Z. S., Brüggemann, N., Butterbach-Bahl, K., Liu, C. Y., Han, S. H., Han, X. G., Zheng, X. H. (2010): Annual methane uptake by typical semiarid steppe in Inner Mongolia. - Journal of Geophysical Research 115: D15108.

[7] Chen, X. P., Wang, G. X., Zhang, T., Mao, T. X., Wei, D., Song C. L., Hua, Z. Y., Huang, K. W. (2017): Effects of warming and nitrogen fertilization on GHG flux in an alpine swamp meadow of a permafrost region. - Science of The Total Environment 601602: 1389-1399.

[8] Dörr, H., Katruff, L., Levin, I. (1993): Soil texture parameterization of $\mathrm{CH}_{4}$ uptake in aerated soils. - Chemosphere 26: 697-713.

[9] Geng, Y. B., Luo, G. Q., Yuan, G. F. (2010): $\mathrm{CH}_{4}$ uptake flux of Leymus chinensis steppe during rapid growth season in Inner Mongolia, China. - Science China 53: 977-983. 
[10] Godsey, C. B., Pierzynski, G. M., Mengel, D. B., Lamond, R. E. (2007): Changes in soil $\mathrm{pH}$, organic carbon, and extractable aluminum from crop rotation and tillage. - Soil Science Society America Journal 71: 1038-1044.

[11] Hütsch, B. W., Webster, C. P., Powlson, D. S. (1993): Long-term effects of nitrogen fertilization on methane oxidation in soil of the Broadbalk wheat experiment. - Soil Biology \& Biochemistry 25: 1307-1315.

[12] IPCC. (2007): Climate Change. The Physical Science Basis. - Contribution of Working Group I to the Fourth Assessment Report of the Intergovernmental Panel on Climate Change. Cambridge University Press, Cambridge, pp. 539-542.

[13] Jacinthe, P. A., Lal, R. (2005): Labile carbon and methane uptake as affected by tillage intensity in a Mollisol. - Soil \&Tillage Research 80: 35-45.

[14] Khalil, M. A. K. (2000): Atmospheric methane. - In: Kahlil, M. A. K. (ed.) Atmospheric Methane, I Role in the Global Environment. Springer, Berlin, pp. 1-8.

[15] Lim, S. S., Choi, W. J. (2014): Changes in microbial biomass, $\mathrm{CH}_{4}$ and $\mathrm{CO}_{2}$ emissions, and soil carbon content by fly ash co-applied with organic inputs with contrasting substrate quality under changing water regimes. - Soil Biology \& Biochemistry 68: 494502.

[16] Liu, C., Holst, J., Bruggemann, N., Butterbach-Bahl, K., Yao, Z. S., Yue, J., Han, S. H., Han, X. G., Krümmelbein, J., Horn, R., Zheng, X. H. (2007): Winter-grazing reduces methane uptake by soils of a typical semi-arid steppe in Inner Mongolia, China. Atmospheric Environment 41: 5948-5958.

[17] Liu, X. H., Lu, X. G., Jiang, M., Wang, X. G. (2009): Value estimation of greenhouse gases exchange in wetland ecosystem of Sanjiang Plain, China. - Chinese Geographical Science 19(1): 55-61. doi.org/10.1007/s11769-009-0055-7.

[18] Merino, A., Perez-Batallon, P., Macas, F. (2004): Responses of soil organic matter and greenhouse gas fluxes to soil management and land use changes in a humid temperature region of southern Europe. - Soil Biology \& Biochemistry 36: 917-925.

[19] Mosier, A. R., Parton, W. J., Phongpan, S. (1998): Long-term large N and immediate small $\mathrm{N}$ addition effects on trace gas fluxes in the Colorado shortgrass steppe. - Biology and Fertility of Soils 28: 44-50.

[20] Mou, X. J., Liu, X. T., Tong, C., Sun Z. G. (2014): Responses of $\mathrm{CH}_{4}$ emissions to nitrogen addition and Spartina alterniflora invasion in Minjiang River estuary, southeast of China. - Chinese Geographical Science 24(5): 562-574. doi: 10.1007/s11769-0140692-3.

[21] Nunan, N., Morgan, M. A., Herlihy, M. (1997): Ultraviolet absorbance (280nm) of compounds released from soil during chloroform fumigation as an estimate of the microbial biomass. - Soil Biology \& Biochemistry 30: 1599-1603.

[22] Ojima, D. S., Valentine, D. W., Mosier, A. R. (1993): Effect of land use change on methane oxidation in temperate forest and grassland soils. - Chemosphere 26: 675-685.

[23] Price, S. J., Sherlock, R. R., Kelliher, F. M., McSeveny, T. M., Tate, K. R., Condron, L. M. (2004): Pristine New Zealand forest soil is a strong methane sink. - Global Change Biology 10: 16-26.

[24] Rong, Y. P., Ma, L., Johnson, D. A. (2015): Methane uptake by four land-use types in the agro-pastoral region of northern China. - Atmospheric Environment 116: 12-21.

[25] Sitaula, B. K., Bakken, L. R., Abrahamsen, G. (1995): $\mathrm{CH}_{4}$ uptake by temperate forest soil effect of $\mathrm{N}$ input and soil acidification. - Soil Biology \& Biochemistry 27: 871-880.

[26] Smith, K. A., Dobbie, K. E., Ball, B. C. (2000): Oxidation of atmospheric methane in northern European soils, comparison with other ecosystems, and uncertainties in the global terrestrial sink. - Global Change Biology 6: 791-803.

[27] Steudler, P. A., Jones, R. D., Castro, M. S., Melillo, J. M., Lewis, D. L. (1995): Microbial controls of methane oxidation in temperate forest and agricultural soils. - In: Murrel, J. C., Kelly, D. P. (eds.) Microbiology of atmospheric Trace Gases. Sources, Sinks and Global Change Processes. NATOASI Series Vol I 39. Springer-Verlag, Berlin, pp. 67-84. 
[28] Tong, C., Wu, J., Yong, S., Yang, J., Yong, W. (2004): A land scape-scale assessment of steppe degradation in the Xilin River Basin, Inner Mongolia, China. - Journal of Arid Environment 59: 133-149.

[29] Verchot, L. V., Davidson, E. A., Cattanio, J. H., Ackerman, I. L. (2000): Land-use change and biogeochemical controls of methane fluxes in soils of eastern Amazonia. Ecosystems 3: 41-56.

[30] Wang, Y., Wang, Y. (2003): Quick measurement of $\mathrm{CH}_{4}, \mathrm{CO}_{2}$ and $\mathrm{N}_{2} \mathrm{O}$ emissions from a short-plant ecosystem. - Advances in Atmospheric Sciences 20: 842-844.

[31] Wang, Y. S., Xue, M., Zheng, X. H., Ji, B. M., Du, R., Wang, Y. F. (2005): Effects of environmental factors on $\mathrm{N}_{2} \mathrm{O}$ emission from and $\mathrm{CH}_{4}$ uptake by the typical grasslands in the Inner Mongolia. - Chemosphere 58: 205-216.

[32] Wang, Z. P., Li, L. H., Han, X. G., Li, Z. Q., Chen, Q. S. (2007): Dynamics and allocation of recently photo-assimilated carbon in an Inner Mongolia temperate steppe. Environmental and Experimental Botany 59: 1-10.

[33] Wang, X. Y., Zhang, Y. J., Huang, D., Li, Z. Q., Zhang, X. Q. (2015): Methane uptake and emissions in a typical steppe grazing system during the grazing season. Atmospheric Environment 105: 14-21.

[34] Yan, Y., Tian, J., Fan, M. S., Zhang, F. S., Li, X. L., Christie, P., Chen, H. Q., Lee, J., Kuzyakov, Y., Six, J. (2012): Soil organic carbon and total nitrogen in intensively managed arable soils. - Agriculture Ecosystems \& Environment 150: 102-110.

[35] Yang, W. Z., Yang, M. D., Wen, H. Y., Jiao, Y. (2018): Global Warming Potential of $\mathrm{CH}_{4}$ uptake and $\mathrm{N}_{2} \mathrm{O}$ emissions in saline-alkaline soils. - Atmospheric Environment 191: 172-180.

[36] Yang, W. Z., Jiao, Y., Yang, M. D., Wen, H. Y. (2018): Methane uptake by salinealkaline soils with varying electrical conductivity in the Hetao Irrigation District of Inner Mongolia, China. - Nutrient Cycling in Agroecosystems 112: 265-276. 